\title{
‥
}

\section{RESEARCH AND EDUCATION \\ Effect of different methods of polymerizing ocular prosthesis acrylic resin on a human conjunctival cell line}

\author{
Emily Vivianne Freitas da Silva, DDS, MS, ${ }^{a}$ Marcelo Coelho Goiato, MS, PhD, ${ }^{b}$ \\ Daniela Micheline dos Santos, MS, PhD, ${ }^{c}$ Liliane da Rocha Bonatto, DDS, MS, ${ }^{d}$ \\ Victor Gustavo Balera Brito, PhamD, ${ }^{e}$ and Sandra Helena Penha de Oliveira, MS, PhD ${ }^{f}$
}

The ocular prosthesis is a treatment option that should be provided as soon as possible for patients with anophthalmia. ${ }^{1,2}$ Acrylic resin (AR) for artificial sclera (N1 color) and colorless AR are materials commonly used for fabricating the prosthesis. ${ }^{1,3-5}$ A polymerization reaction begins after mixing the powder and liquid, which enables monomer to polymer conversions. ${ }^{6-9}$ AR can be polymerized in a water bath or using microwave energy, or it can be chemically activated. ${ }^{6,10-16}$ Incomplete reactions result in the presence of residual methylmethacrylate (MMA) monomer and other possibly toxic chemicals, such as formaldehyde, benzoic acid, methacrylic acid, phenyl salicylate, dibutyl phthalate, and phenyl benzoate. ${ }^{11,12,17-20}$

\begin{abstract}
Statement of problem. Ocular prosthesis acrylic resins should be biocompatible regardless of the polymerization method. The authors are unaware of a study that evaluated the biocompatibility of ocular prostheses.
\end{abstract}

Purpose. The purpose of this in vitro study was to evaluate the cytotoxicity of different methods of polymerizing ocular prosthesis acrylic resin. This was accomplished by analyzing the cell proliferation, production of proinflammatory cytokines, and expression of extracellular matrix proteins related to tissue remodeling and repair of a human conjunctival cell line.

Material and methods. Nine acrylic resin specimens were divided into 3 groups: polymerization in a water bath, by microwave, or by autopolymerization. Eluates (prepared for 72 hours) were exposed to cells for 72 hours. A medium without specimens served as negative control (nonstimulated group). The tetrazolium dye MTT (3-[4,5-dimethylthiazol-2-yl]-2,5-diphenyl tetrazolium bromide) assay was performed to evaluate the cytotoxic effect, and an enzyme-linked immunosorbent assay was executed for analysis of interleukin $1 \beta$ (IL1 $\beta$ ), IL6, tumor necrosis factor $\alpha$ (TNF $\alpha$ ), and CCL3/MIP1 $\alpha$ production. Also, real-time reverse transcriptase (RT)-PCR was performed for analysis of mRNA expression of type IV collagen (COL IV), TGF $\beta$, and MMP9, and data were tested using ANOVA with Bonferroni post hoc test $(\alpha=.05)$.

Results. Microwave-processed resin showed slight cytotoxicity due to a significant reduction in cell proliferation and an increase in IL6 quantity. Higher levels of mRNA expression of COL IV, MMP9, and TGF $\beta$ were verified in water bath-processed resin, which were similar to those in the nonstimulated group.

Conclusions. Microwave-processed resin showed a significant reduction in cell proliferation and an increase in IL6 quantity. Heat-polymerized resin exhibited a higher mRNA expression of COL IV, MMP9, and TGF $\beta$; this result was similar to that in the nonstimulated group. (J Prosthet Dent 2016;116:818-823)

\footnotetext{
Supported by the National Council for Scientific and Technological Development, Coordination for the Improvement of Higher Education Personnel, and Foundation for Support to Research of the State of São Paulo scholarship 2013/11830-4 (to E.V.F.d.S.).

aPostgraduate student, Department of Dental Materials and Prosthodontics, Aracatuba Dental School, São Paulo State University, São Paulo, Brazil.

bProfessor, Department of Dental Materials and Prosthodontics, Aracatuba Dental School, São Paulo State University, São Paulo, Brazil.

${ }^{\mathrm{c}}$ Professor, Department of Dental Materials and Prosthodontics, Aracatuba Dental School, São Paulo State University, São Paulo, Brazil.

${ }^{\mathrm{d} P}$ Postgraduate student, Department of Dental Materials and Prosthodontics, Aracatuba Dental School, São Paulo State University, São Paulo, Brazil.

eGraduate student, Department of Basic Sciences, Aracatuba Dental School, São Paulo State University, São Paulo, Brazil.

fProfessor, Department of Basic Sciences, Aracatuba Dental School, São Paulo State University, São Paulo, Brazil.
} 


\section{Clinical Implications}

Clinicians should be aware of available methods for polymerization of ocular prosthesis acrylic resins. The ocular prosthesis should be processed in a water bath, as these specimens exhibited a result similar to that of the nonstimulated group.

The polymerization method used has a direct influence on the amount of residual monomer released, resulting in different cytotoxicity levels, ${ }^{21-23}$ which can interfere with the success of the rehabilitation. ${ }^{12,24}$ These cytotoxicity levels can be evaluated with in vitro tests to ensure material biocompatibility in humans. Among the available resources, the cell culture method has the advantages of simplicity and reproducibility. ${ }^{24-26}$

Using the cell culture method, material cytotoxicity can be evaluated by using primary cells or cell line analogous to the target organ. ${ }^{24}$ Human conjunctival cell lines can be used for ocular prosthesis analysis. The conjunctiva, a thin, resistant, and highly vascularized mucous membrane which protects the eye from infections and foreign bodies, ${ }^{27-29}$ acts as a support tissue for the ocular prosthesis. Its use has been widely reported in vitro studies. ${ }^{30-36}$

The authors could find no studies regarding ocular prosthesis biocompatibility. However, knowledge of this biological property is necessary to ensure the safe use of these prostheses in patients. Therefore, this study evaluated the cytotoxic effect of different polymerization methods of N1 color AR. Human conjunctival cells were used for cell proliferation analysis using tetrazolium dye MTT (3-[4,5-dimethylthiazol-2-yl]-2,5-diphenyl tetrazolium bromide) assay, quantification of proinflammatory cytokine production through enzyme-linked immuneabsorbent assay (ELISA), and evaluation of gene expression of extracellular matrix proteins related to tissue remodeling and repair by real-time reverse transcription-polymerase chain reaction (RT-PCR). The null hypothesis was that ocular prosthesis N1 color AR does not produce toxic effects on the cell line studied, regardless of polymerization method.

\section{MATERIAL AND METHODS}

Nine specimens of N1 color AR $(10-\mathrm{mm}$ diameter $\times 3-\mathrm{mm}$ thick; Artigos Odontológicos Clássico Ltda) were fabricated and then polymerized by 3 different methods $(n=3)$ (Table 1$)^{25}$ : heat polymerization by water bath (WB), microwave energy (MW), and autopolymerization (AP). ${ }^{37-42}$

Eluates of substances leached into the aqueous medium were used for cytotoxicity analysis. ${ }^{25,43,44}$ Three specimens from each group were inserted into a sterile
Table 1. Material, commercial brand, chemical composition, and polymerization methods according to manufacturer's instructions

\begin{tabular}{|c|c|c|c|}
\hline Material & $\begin{array}{c}\text { Commercial } \\
\text { Brand }\end{array}$ & Chemical Composition & Polymerization Method \\
\hline \multirow[t]{3}{*}{$\begin{array}{l}\text { Acrylic } \\
\text { resin } \\
\text { liquid }\end{array}$} & Clássico & $\begin{array}{l}\text { MMA monomer, alkylated } \\
\text { phenol (Topanol)* }\end{array}$ & $\begin{array}{l}\text { Heat polymerization in } \\
\text { water bath: immerse flask in } \\
\text { water, apply low heat for } 30 \\
\text { min, turn off heat for } 30 \text { min, } \\
\text { boil for } 1 \mathrm{~h}\end{array}$ \\
\hline & Onda Cryl & $\begin{array}{l}\text { MMA monomer, alkylated } \\
\text { phenol (Topanol), } \\
\text { ethylene glycol } \\
\text { dimethacrylate }\end{array}$ & $\begin{array}{l}\text { Polymerization by } \\
\text { microwave energy: place } \\
\text { flask in microwave } \\
\text { (Brastemp); microwave for } \\
3 \text { min at } 30 \% \text { power, } \\
4 \text { minutes at } 0 \% \text { power, and } \\
3 \text { min at } 60 \% \text { power }\end{array}$ \\
\hline & Jet & $\begin{array}{l}\text { MMA monomer, inhibitor, } \\
\text { dimethyl toluidine }\end{array}$ & $\begin{array}{l}\text { Autopolymerization: open } \\
\text { flask in a device with } 140 \\
\mathrm{kPa} \text { for } 20 \text { min }\end{array}$ \\
\hline $\begin{array}{l}\text { Acrylic } \\
\text { resin } \\
\text { powder }\end{array}$ & $\begin{array}{l}\mathrm{N} 1 \text { acrylic } \\
\text { resin }\end{array}$ & $\begin{array}{l}\text { MMA polymer, } \\
\text { dibuthylftalato, ethyl } \\
\text { acrylate, pigments }\end{array}$ & - \\
\hline
\end{tabular}

MMA, methylmethacrylate. *Alkylated phenol (Topanol), 2,4-dimethyl-6-tert-butylphenol.

vial with $10 \mathrm{~mL}$ of Medium 199 (Gibco) supplemented with $10 \%$ fetal bovine serum (FBS) and incubated at $37^{\circ} \mathrm{C}$ for 72 hours to allow the leaching of substances for the medium. Then, the eluate was sterilized with $0.22-\mu \mathrm{m}$ filters (Millex; Millipore). ${ }^{11,24}$

The cell culture of the human conjunctival cells (Wong Kilbourne derivative of Chang conjunctival cell line; clone 1-5c-4) obtained from American Type Culture Collection (CCL-20.2) was expanded in flasks with Medium 199. The medium was supplemented with $10 \% \mathrm{FBS}, 10 \mu \mathrm{g} / \mathrm{mL}$ penicillin, $10 \mu \mathrm{g} / \mathrm{mL}$ streptomycin, $10 \mu \mathrm{g} / \mathrm{mL}$ gentamicin, and $250 \mu \mathrm{g} / \mathrm{mL}$ fungizone, and incubated in $5 \% \quad \mathrm{CO}_{2}$ and controlled humidity at $37^{\circ} \mathrm{C} .31,35,36,45$ One milliliter of medium with a cell suspension of $5 \times 10^{4}$ cells $/ \mathrm{mL}$ was then pipetted into a 24 -well plate. The medium was replaced by $500 \mu \mathrm{L}$ of eluates from each polymerization group after 24 hours. Medium 199 (with 10\% FBS but without specimens) served as negative control (nonstimulated [NS] group). ${ }^{11,31}$ The positive control consisted of wells with Tween 20 (Sigma-Aldrich). The same incubation and temperature conditions were used to determine the eluates.

After cells were exposed to eluates for 72 hours, the culture medium was replaced by $500 \mu \mathrm{L}$ of Medium 199 . The medium contained $0.5 \mathrm{mg} / \mathrm{mL}$ MTT and had been incubated with $5 \% \mathrm{CO}_{2}$ at $37^{\circ} \mathrm{C}$ for 4 hours. It did not contain FBS. ${ }^{11,24,46}$ Intracellular formazan dye was released using solubilization with $1 \mathrm{~mL}$ of isopropanol per well, and absorbance was measured with a spectrophotometer (SpectraMax 190; Molecular Devices) at $570 \mathrm{~nm}$. The MTT assay was performed in triplicate. ${ }^{24-26,46}$

Cell-free supernatants were collected after 72 hours of eluate exposition to the cells to execute the ELISA. The 
aim of the collection was to quantify different cytokines $^{47,48}$ : interleukin 6 (IL6), IL1 $\beta$, tumor necrosis factor $\alpha(\mathrm{TNF} \alpha)$, and chemokine macrophage inflammatory protein $1 \alpha$ (CCL3/MIP1 $\alpha$ ). A total of $100 \mu \mathrm{L}$ of the supernatant was used for quantitative analysis. The assay (DuoSet ELISA development systems; R\&D System) was performed in triplicate, according to the manufacturerl's recommendations. ${ }^{45,49-51}$

The quantitative analysis of gene expression for type IV collagen (COL IV; COL4A3BP; Hs00178621_m1; Thermo Fisher Scientific), matrix metalloproteinase 9 (MMP9; MMMP9: Hs00234579_m1; Thermo Fisher Scientific), and transforming growth factor $\beta$ (TGF $\beta$; TGFB1: Hs0099133_m1; Thermo Fisher Scientific) ${ }^{49}$ was performed through real-time reverse-transcriptase (RT)PCR. These targets are part of the tissue repair process. ${ }^{52-}$

${ }^{56}$ TRIzol reagent (Invitrogen Life Technologies) was used for RNA extraction after 72 hours of eluate exposition to the cells, and RNA concentration was measured by spectrophotometry. One microgram of total RNA and Superscript II RNase $\mathrm{H}^{-}$reverse transcriptase (Invitrogen Life Technologies) was used to synthesize first-strand cDNA. Posteriorly, mRNA levels were measured and amplified by using a StepOnePlus real-time PCR system (Invitrogen Life Technologies). The internal control was the detection of mRNA for $\beta$-actin (ACTB; Hs03023880_g1) and a volume of $20 \mu \mathrm{L}$ to perform the reactions. Each specimen was run in duplicate, according to the thermal cycling conditions established by the manufacturer, and the comparative threshold cycle $\left(\mathrm{C}_{\mathrm{T}}\right)$ method was used to analyze the results.

Data obtained from MTT, ELISA, and real-time RTPCR assays were submitted to one-factor analysis of variance (ANOVA) with Bonferroni post hoc test $(\alpha=.05)$.

\section{RESULTS}

Figure 1 shows the cell proliferation percentage for the various polymerization methods assessed. A statistical difference was observed among the groups $(d f=4$; $\mathrm{F}=593.779 ; P<.001)$. The WB $(88.4 \%)$ and MW (74.9\%) groups exhibited lower cell proliferation percentages, with statistically significant differences from that of the NS group (100\%).

No detectable levels of IL1 $\beta$ or CCL3/MIP1 $\alpha$ were found in the present study. However, high IL6 levels were observed for the tested groups. In addition, this concentration differed significantly among the polymerization methods assessed $(d f=3 ; F=12.266 ; P<.006)$. Statistically higher concentrations were verified for the MW group $(14.199 \mathrm{pg} / \mathrm{mL})$ than for the NS $(9.842 \mathrm{pg} / \mathrm{mL})$ and AP (10.248 pg/mL) groups. No statistically significant differences were seen among the WB group (12.374 $\mathrm{pg} / \mathrm{mL}$ ) and the other groups. No statistically significant differences in $\mathrm{TNF} \alpha$ concentrations were observed

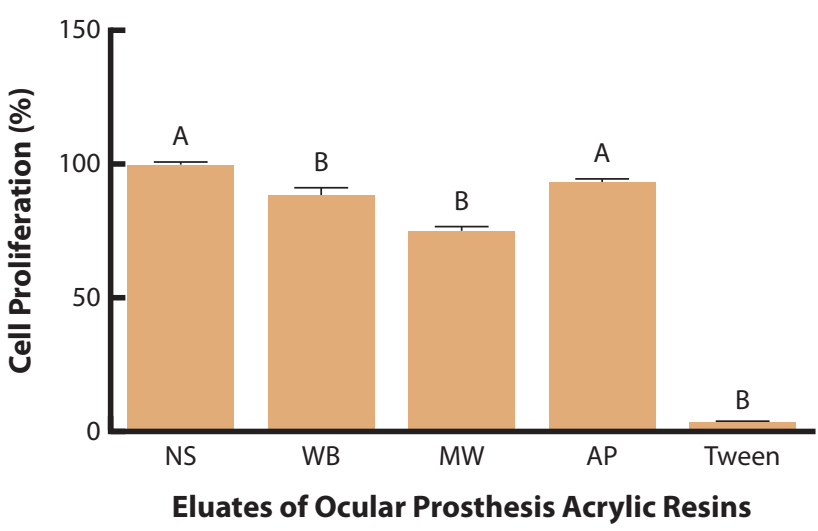

Figure 1. Percentages of cell proliferation for the assessed polymerization methods. Results show mean $\pm S D$ cell proliferation percentage. Letters $A$ and $B$ indicate statistical differences $(P<.05)$ compared with respective group NS. AP, autopolymerization; $M W$, polymerization by microwave energy; NS, nonstimulated group; WB, heat-polymerization in water bath.

among the polymerization methods evaluated $(d f=3$; $\mathrm{F}=2.684 ; P=.182)$.

Regarding the relative quantification of mRNA for COL IV for the various polymerization methods assessed, statistical differences were observed among the groups $(d f=3 ; \mathrm{F}=32.076 ; P<.001)$. The WB (2.21-fold) and NS (2.01-fold) groups showed higher gene expression levels of COL IV than the MW (0.99-fold) and AP (1.25fold) groups that were significantly different.

Statistically significant differences were observed in the relative quantification of mRNA for MMP9 for the tested groups $(d f=3 ; \mathrm{F}=19.903 ; P<.001)$. The WB (5.75fold) and NS (5.77-fold) groups presented higher gene expression levles of MMP9 than the MW (1.80-fold) and AP (1.65-fold) groups, with statistical differences.

Regarding the relative quantification of mRNA for TGF $\beta$, a statistical difference $(d f=3 ; \mathrm{F}=14.226 ; P<.001)$ was found because the WB (2.02-fold) and NS (1.80-fold) groups had higher gene expression levels of TGF $\beta$ than the MW (0.75-fold) and AP (0.66-fold) groups.

\section{DISCUSSION}

The null hypothesis that ocular prosthesis resin does not produce toxic effects on the cell line, regardless of the polymerization method studied, was rejected. The resins exhibited different behaviors with regard to the assays performed.

Water bath polymerization is one of the methods used most for prosthesis fabrication because it is less expensive than microwave energy polymerization and produces prostheses with suitable mechanical properties. ${ }^{9,10}$ However, an increase in surface porosity can occur due to the exothermic polymerization reaction. ${ }^{6}$ Chemically activated resin is commonly used to repair 
prostheses, because it is rapidly polymerized at room temperature. ${ }^{20}$

As far as the authors are aware, the different methods of polymerizing ocular prosthesis resin have not previously been investigated for cytotoxicity. However, chemical activation of a denture resin causes greater cell proliferation inhibition than other methods. ${ }^{11,13,22}$ This is due to a lower conversion degree and consequently higher amounts of MMA monomer. ${ }^{9}$

However, there was no cell proliferation reduction in the AP group in this study compared with that in the NS group (Fig. 1). This may be due to polymerization conducted with an open flask and pressure for 20 minutes, according to the manufacturer's instructions, to prevent material porosity. ${ }^{14}$ Release of residual monomer may have begun before specimen immersion in the vial with the culture medium for obtaining eluate. This was contrary to the condition of the resins polymerized by other methods, where flask cooling was done previous to deflasking the specimens. Furthermore, part of the residual monomer from the AP group may not have spread into the aqueous medium. Instead, they may have remained in the resin matrix as pendant chains. , $^{80}$

Microwave energy polymerization has the advantages of reducing polymerization time with improved homogeneity between the powder and liquid and of excellent adaptation of the prosthesis. ${ }^{4,8,40}$ However, the flask must be cooled before opening after polymerization, as with water bath polymerization. Additionally, this method has a higher cost because it requires microwave equipment and specific flasks. ${ }^{10}$

Compared with the NS group, the WB-polymerized material can be considered noncytotoxic (cell proliferation higher than $75 \%$ ). The MW group, however, provided slight cytotoxicity (proliferation between 50\% and 75\%) (Fig. 1) according to International Standards Organization ISO 10993-5 standard, which provides a classification for in vitro methods of cytotoxicity analysis. ${ }^{43}$ Similarly, Sheridan et $\mathrm{al}^{13}$ observed that after 96 hours of eluate obtainment, a denture polymerized in water bath was less cytotoxic than a resin polymerized with microwaves.

Azzarri et $\mathrm{al}^{8}$ stated that cytotoxicity can be influenced by parameters of duration and microwave power. Also, microwave energy action occurs only on the monomer molecules. ${ }^{26,40}$ In the present study, MW polymerization was performed in a dry area according to the manufacturer's recommendations. However, the degree of conversion achieved mignt not have been sufficient to reduce the cytotoxic potential of the material. According to Jorge et $\mathrm{al}^{21}$ and Sheridan et $\mathrm{al}_{1}{ }^{13}$ the diffusion of various potentially toxic substances such as formaldehyde, methacrylic acid, benzoic acid, phenyl benzoate, and organic additives among others, which are not influenced by microwave energy, may be responsible for the cytotoxicity. This hypothesis can explain the slight cytotoxicity observed for the MW group. Oxygen may bind to free binding sites of the polymer chain, inhibiting their occupancy by monomer molecules and, consequently, the polymerization. ${ }^{21}$

The flask had to cool before being opened, which may be associated with a MW group cell proliferation that was lower than that for the AP group, whose polymerization reaction was without the confinement conditions. These hypotheses can justify the higher concentrations of IL6 for the MW group. The IL6 target is one of the major interleukins responsible for increasing the local concentration of cells for tissue repair. ${ }^{47,48}$

The different properties of resins polymerized by microwave energy, such as flexural strength, dimensional stability, and hardness, have been studied, ${ }^{4,15,16,42}$ and excellent results were observed. However, regarding cytotoxicity, this method does not seem to be the most suitable for polymerization of N1 color AR. Resin for ocular prostheses differs from denture resin because of the smaller granulation of the MMA polymer powder. ${ }^{5}$

Jorge et $\mathrm{al}^{23}$ compared WB- and MW-polymerized denture resin and found similar results for cell proliferation. However, the eluate preparation period was 24 hours, which differred from the 72-hour period used in this study. According to Cimpan et $\mathrm{al}^{, 4}$ the higher the dose and the longer eluates are exposed to cells, the greater the deleterious effects. Therefore, the 72-hour period may have influenced MW group cytotoxicity.

Regarding the expression levels of COL IV, MMP9, and TGF $\beta$ mRNA, higher values were observed for the WB group. However, the values were similar to those of the NS group, indicating that the tested cells appear to produce those targets under physiological conditions. The balance between the synthesis and breakage of collagen is important for avoiding a fibrous reaction during the tissue repair process. ${ }^{52,53} \mathrm{COL} \mathrm{IV}$, produced by epithelial cells, is essential in the composition of their basement membrane extracellular matrix. ${ }^{54}$ Preservation of cell structure is related to the balance of the relative quantification of mRNA for the tested targets. A similarity was observed in mRNA expression for COL IV and TGF $\beta$, which is responsible for stimulating the synthesis of COL IV. ${ }^{47,55}$ The gene expression of MMP9, responsible for the degradation of COL $\mathrm{IV}^{47,55}$ was approximately 3 times higher than the expression of COL IV and TGF $\beta$. This may be deleterious and result in severe cell morphology damage. ${ }^{56}$

The polymerization cycle of the WB group was performed within a 2-hour duration (Table 1), in accordance with the manufacturer's instructions. The influence of using different cycles for the polymerization of denture AR was evaluated by Bural et al. ${ }^{7}$ The authors found that, although the manufacturer recommended a polymerization of 1 hour, consisting of 30 minutes in heated water and 30 minutes of boiling, the long polymerization cycle 
of 9 hours of immersion in heated water, associated with 30 minutes of boiling, significantly reduced the amount of residual monomer released into the culture medium. It also increased the cell proliferation percentage in the eluates formed for 24 and 48 hours.

Different cell lines were used to assess the cytotoxicity of the AR in these studies, which may have influenced the cellular response found. ${ }^{17}$ In addition, the authors are unaware of reports concerning the evaluation of the Wong-Kilbourne derivative of Chang conjunctival cell line exposed to AR. These cells have been widely used in in vitro studies, ${ }^{30-33}$ because they correspond to cells from human conjunctiva, which cover the posterior part of the lid and extend to the posterior, covering the sclera. ${ }^{27,28}$

One limitation of the present study is the presence of differences between the periods for specimen deflasking for each polymerization method. However, the instructions of the manufacturer were followed. Additionally, in vitro tests were executed, which despite not reflecting the clinical condition use of the material, were essential for the analysis of biological behavior. From a clinical point of view, the results should be interpreted with caution. Further studies are needed to assess the cytotoxicity caused by different polymerization cycles of N1 color AR and to investigate the colorless resin used for coating the characterization of an ocular prosthesis, regarding the different polymerization methods.

\section{CONCLUSIONS}

Based on the results of the in vitro testing in this study, the following conclusions were drawn:

1. Resins submitted to different polymerization methods exhibited divergent biological behavior.

2. The MW group showed a significant cell proliferation reduction and IL6 quantity increase.

3. The WB group exhibited comparable behavior to the NS group (higher mRNA expression of COL IV, MMP9, and TGF $\beta$ ), making it the most appropriate method for fabricating ocular prostheses.

\section{REFERENCES}

1. Prithviraj DR, Gupta V, Muley N, Suresh P. Custom ocular prosthesis: comparison of two different techniques. J Prosthodont Res 2013;57:129-34.

2. Goiato MC, Santos DM, Gennari Filho H, Zavanelli AC, Dekon SFC, Mancuso DN. Influence of investment, disinfection, and storage on the microhardness of ocular resins. J Prosthodont 2009:18:32-5.

3. Goiato MC, Bannwart LC, Haddad MF, dos Santos DM, Pesqueira AA, Miyahara GI. Fabrication techniques for ocular prostheses-an overview. Orbit 2014:33:229-33.

4. Fernandes AU, Portugal A, Veloso LR, Goiato MC, Santos DM. Assessment of the flexural strength of two heat-curing acrylic resins for artificial eyes. Braz Oral Res 2009;23:263-7.

5. Fernandes AUR, Goiato MC, Santos DM. Effect of weathering and thickness on roughness of acrylic resin and ocular button. Cont Lens Anterior Eye 2010;33:124-7.

6. Canadas MD, Garcia LF, Consani S, Pires-de-Souza FC. Color stability, surface roughness, and surface porosity of acrylic resins for eye sclera poly merized by different heat sources. J Prosthodont 2010;19:52-7.
7. Bural C, Aktaş E, Deniz G, Ünlüçerçi Y, Bayraktar G. Effect of leaching residual methyl methacrylate concentrations on in vitro cytotoxicity of heat polymerized denture base acrylic resin processed with different polymerization cycles. J Appl Oral Sci 2011;19:306-12.

8. Azzarri MJ, Cortizo MS, Alessandrini JL. Effect of the curing conditions on the properties of an acrylic denture base resin microwave-polymerised J Dent 2003;31:463-8.

9. Anusavice KJ, Shen C, Rawls HR. Phillips' science of dental materials. 12th ed. St. Louis, MO: Elsevier; 2012:474-98.

10. Blagojevic V, Murphy VM. Microwave polymerization of denture base materials. A comparative study. J Oral Rehabil 1999;26:804-8.

11. Ata SO, Yavuzyilmaz H. In vitro comparison of the cytotoxicity of acetal resin, heat-polymerized resin, and auto-polymerized resin as denture base materials. J Biomed Mater Res B Appl Biomater 2009;91:905-9.

12. Att W, Yamada M, Kojima N, Ogawa T. N-Acetyl cysteine prevents suppression of oral fibroblast function on poly(methylmethacrylate) resin. Acta Biomater 2009;5:391-8.

13. Sheridan PJ, Koka S, Ewoldsen NO, Lefebvre CA, Lavin MT. Cytotoxicity of denture base resins. Int J Prosthodont 1997:10:73-7.

14. Donovan TE, Hurst RG, Campagni WV. Physical properties of acrylic resin polymerized by four different techniques. J Prosthet Dent 1985; 54:522-4.

15. Farina AP, Cecchin D, Soares RG, Botelho AL, Takahashi JMFK, Mazzetto MO, et al. Evaluation of Vickers hardness of different types of acrylic denture base resins with and without glass fibre reinforcement. Gerodontology 2012;29:e155-60.

16. Banerjee R, Banerjee S, Prabhudesai PS, Bhide SV. Influence of the processing technique on the flexural fatigue strength of denture base resins: an in vitro investigation. Indian J Dent Res 2010;21:391-5.

17. Chaves CA, Machado AL, Vergani CE, de Souza RF, Giampaolo ET. Cytotoxicity of denture base and hard chairside reline materials: a systematic review. J Prosthet Dent 2012;107:114-27.

18. Saravi ME, Vojdani M, Bahrani F. Evaluation of cellular toxicity of three denture base acrylic resins. J Dent (Tehran) 2012;9:180-8.

19. Tay LY, Herrera DR, Quishida CC, Carlos IZ, Jorge JH. Effect of water storage and heat treatment on the cytotoxicity of soft liners. Gerodontology 2012;29: e275-80.

20. Bural C, Aktaş E, Deniz G, Ünlüçerçi Y, Kızılcan N, Bayraktar G. Effect of post-polymerization heat-treatments on degree of conversion, leaching residual MMA and in vitro cytotoxicity of autopolymerizing acrylic repair resin. Dent Mater 2011;27:1135-43.

21. Jorge JH, Giampaolo ET, Vergani CE, Machado AL, Pavarina AC, Carlos IZ. Effect of post-polymerization heat treatments on the cytotoxicity of two denture base acrylic resins. J Appl Oral Sci 2006;14:203-7.

22. Huang FM, Tai KW, Hu CC, Chang YC. Cytotoxic effects of denture base materials on a permanent human oral epithelial cell line and on primary human oral fibroblasts in vitro. Int J Prosthodont 2001;14:439-43.

23. Jorge JH, Giampaolo ET, Vergani CE, Pavarina AC, Machado AL, Carlos IZ. Effect of microwave postpolymerization treatment and of storage time in water on the cytotoxicity of denture base and reline acrylic resins. Quintes sence Int 2009;40:e93-100.

24. Bal BT, Yilmaz H, Aydın C, Karakoca S, Yilmaz S. In vitro cytotoxicity of maxillofacial silicone elastomers: effect of accelerated aging. J Biomed Mater Res Part B Appl Biomater 2009;89:122-6.

25. Jorge JH, Giampaolo ET, Vergani CE, Machado AL, Pavarina AC, Carlos IZ. Biocompatibility of denture base acrylic resins evaluated in culture of L929 cells. Effect of polymerisation cycle and post-polymerisation treatments. Gerodontology 2007:24:52-7.

26. Jorge JH, Giampaolo ET, Vergani CE, Machado AL, Pavarina AC, Carlos IZ Cytotoxicity of denture base resins: Effect of water bath and microwave postpolymerization heat treatments. Int J Prosthodont 2004;17:340-4.

27. Barisani-Asenbauer T, Inic-Kanada A, Belij S, Marinkovic E, Stojicevic I, Montanaro J, et al. The ocular conjunctiva as a mucosal immunization route: a profile of the immune response to the model antigen tetanus toxoid. PLoS One 2013:8:e60682.

28. Willoughby CE, Ponzin D, Ferrari S, Lobo A, Landau K, Omido Y. Anatomy and physiology of the human eye: effects of mucopolysaccharidoses disease on structure and function - a review. Clin Exp Ophthalmol 2010;38:2-11.

29. Gipson IK, Argüeso P. Role of mucins in the function of the corneal and conjunctival epithelia. Int Rev Cytol 2003;231:1-49.

30. Ayaki M, Iwasawa A, Niwano Y. Cell viability score as an integrated indicator for cytotoxicity of benzalkonium chloride-containing antiglaucoma eyedrops. Biocontrol Sci 2012;17:121-8.

31. Clouzeau C, Godefroy D, Riancho L, Rostène W, Baudouin C, BrignoleBaudouin F. Hyperosmolarity potentiates toxic effects of benzalkonium chloride on conjunctival epithelial cells in vitro. Mol Vis 2012;18:851-63.

32. Ayaki M, Iwasawa A, Niwano Y. Cytotoxicity assays of new artificial tears containing 2-methacryloyloxyethyl phosphorylcholine polymer for ocular surface cells. Jpn J Ophthalmol 2011;55:541-6.

33. Ayaki M, Iwasawa A, Yaguchi S, Koide R. In vitro assessment of the cytotoxicity of anti-allergic eye drops using 5 cultured corneal and conjunctival cell lines. J Oleo Sci 2011;60:139-44. 
34. Joffre C, Souchier M, Leclere L, Buteau B, Grégoire S, Lizard G, et al Branched-chain fatty acids, increased in tears of blepharitis patients, are not toxic for conjunctival cells. Br J Ophthalmol 2009;93:1391-5.

35. Baudouin C, Riancho L, Warnet JM, Brignole F. In vitro studies of antiglaucomatous prostaglandin analogues: travoprost with and without ben zalkonium chloride and preserved latanoprost. Invest Ophthalmol Vis Sci 2007;48:4123-8.

36. Debbasch C, Brignole F, Pisella PJ, Warnet JM, Rat P, Baudouin C. Quaternary ammoniums and other preservatives' contribution in oxidative stress and apoptosis on Chang conjunctival cells. Invest Ophthalmol Vis Sci 2001;42:642-52.

37. Monteiro DR, Gorup LF, Takamiya AS, de Camaroo ER, Filho AC, Barbosa DB. Silver distribution and release from an antimicrobial denture base resin containing silver colloidal nanoparticles. J Prosthodont 2012;21: 7-15.

38. Goiato MC, Santos DM, Souza JF, Moreno A, Pesqueira AA. Chromatic stability of acrylic resins of artificial eyes submitted to accelerated aging and polishing. J Appl Oral Sci 2010;18:641-5.

39. Goiato MC, Santos DM, Haddad MF, Pesqueira AA. Effect of accelerated aging on the microhardness and color stability of flexible resins for dentures. Braz Oral Res 2010;24:114.

40. Compagnoni MA, Barbosa DB, Souza RF, Pero AC. The effect of polymerization cycles on porosity of microwave-processed denture base resin. J Prosthet Dent 2004;91:281-5.

41. Goiato MC, Dos Santos DM, Moreno A, Iyda MG, Rezende MC, Haddad MF. Effect of disinfection and storage on the flexural strength of ocular prosthetic acrylic resins. Gerodontology 2012;29:e838-44.

42. Miéssi AC, Goiato MC, Santos DM, Dekon SFC, Okida RC. Influence of storage period and effect of different brands of acrylic resin on the dimensional accuracy of the maxillary denture base. Braz Dent J 2008;19: 204-8.

43. International Organization for Standardization. ISO 10993-5: biological evaluation of medical devices-part 5: tests for in vitro cytotoxicity. Geneva: ISO; 2009. Available at: http://www.iso.org/iso/catalogue_detail.htm? csnumber $=36406$. Last accessed June 20, 2016

44. Cimpan MR, Cressey LI, Skaug N, Halstensen A, Lie SA, Gjertsen BT, et al. Patterns of cell death induced by eluates from denture base acrylic resins in U-937 human monoblastoid cells. Eur J Oral Sci 2000:108:59-69.

45. Bernabé DG, Tamae AC, Biasoli ÉR, Oliveira SH. Stress hormones increase cell proliferation and regulates interleukin-6 secretion in human oral squamous cell carcinoma cells. Brain Behav Immun 2011;25:574-83.
46. Gonçalves TS, Schmitt VM, Thomas M, de Souza MAL, de Menezes LM. Cytotoxicity of two autopolymerized acrylic resins used in orthodontics. Angle Orthod 2008;78:926-30.

47. Abbas AK, Lichtman AH, Pillai S. Cellular and molecular immunology. 7th ed. St. Louis, MO: WB Saunders; 2011:55-88.

48. Gabay C. Interleukin-6 and chronic inflammation. Arthritis Res Ther 2006; 8:S3.

49. Oliveira SH, Santos VA. Studies on the expression of fibroblast growth factor-2 from odontoblast-like cells. J Endod 2011;37:1520-4.

50. Trubiani O, Toniato E, Di Iorio D, Diomede F, Merciaro I, D'Arcangelo C, et al. Morphological analysis and interleukin release in human gingival fibroblasts seeded on different denture base acrylic resins. Int J Immunopathol Pharmacol 2012;25:637-43.

51. Moharamzadeh K, Van Noort R, Brook IM, Scutt AM. Cytotoxicity of resin monomers on human gingival fibroblasts and HaCaT keratinocytes. Dent Mater 2007;23:40-4.

52. Tirado-Rodriguez B, Ortega E, Segura-Medina P, Huerta-Yepez S. TGF- $\beta$ : an important mediator of allergic disease and a molecule with dual activity in cancer development. J Immunol Res 2014:2014:318481.

53. Santibañez JF, Quintanilla M, Bernabeu C. TGF- $\beta /$ TGF- $\beta$ receptor system and its role in physiological and pathological conditions. Clin Sci (Lond) 2011;121:233-51.

54. Simon RH, Scott MJ, Reza MM, Killen PD. Type IV collagen production by rat pulmonary alveolar epithelial cells. Am J Respir Cell Mol Biol 1993:8:640-6.

55. Romi F, Helgeland G, Gilhus NE. Serum levels of matrix metalloproteinases: implications in clinical neurology. Eur Neurol 2012;67:121-8.

56. Yang K, Palm J, König JK, Seeland U, Rosenkranz S, Feiden W, et al. Matrixmetallo-proteinases and their tissue inhibitors in radiation-induced lung injury. Int J Radiat Biol 2007;83:665-76.

\section{Corresponding author:}

Dr Marcelo Coelho Goiato

Department of Dental Materials and Prosthodontics

Aracatuba Dental School, São Paulo State University (UNESP)

Jose Bonifacio St, 1153

Vila Mendonca, Aracatuba, São Paulo

BRAZIL

Email: goiato@foa.unesp.br

Copyright (C) 2016 by the Editorial Council for The Journal of Prosthetic Dentistry. 